Japan. J. Med. Sci. Biol., 22, 163-174, 1969

\title{
EFFECTS OF VARIOUS PASSAGES ON SOME PROPERTIES OF AN ATTENUATED STRAIN OF JAPANESE ENCEPHALITIS VIRUS WITH SPECIAL REGARD TO MOSQUITO INFECTIVITY
}

\author{
Mitsuo TAKAHASHI*, SAdao YABE** AND ToshiKo OKADA** \\ * Department of Medical Entomology, National Institute of Health, \\ Shinagawa-ku, Tokyo 141, Japan \\ ** Department of Virology and Rickettsiology, National Institute of Health, \\ Shinagawa-ku, Tokyo 141, Japan
}

(Received: February 5th, 1969)

\begin{abstract}
SUMMARY : The $\mathrm{m}$ strain of an attenuated Japanese encephalitis virus was found not to be infective to the mosquito, Culex tritaeniorhynchus summorosus. Various passages of the virus in hosts including mosquitoes did not essentially modify the non-infective nature of the virus to the mosquito. Neither the intraperitoneal virulence to adult mice nor the optimum $\mathrm{pH}$ of hemagglutinin of $\mathrm{m}$ strain were markedly altered during the passages, always differing from that of representative epidemic strains, parent Mukai and JaGAr $\# 01$.

These findings suggested that the $\mathrm{m}$ strain possessed characters rendering it eligible as a candidate for live attenuated vaccine for swine, which are known to be the most important amplifier of Japanese encephalitis virus in nature.
\end{abstract}

\section{INTRODUCTION}

Recent epidemiological studies of Japanese encephalitis (JE) virus in Japan have confirmed the fact that swine are playing the most important role as the amplifier of the virus in nature (Scherer et al., 1959; Konno et al., 1966; Oya, 1967). The vaccination of swine is thus considered to be a possibly effective means to suppress the spread of the virus among a vector population, and the development of live attenuated $\mathrm{JE}$ vaccine may be suited for this purpose because it may possibly have an excellent immunogenicity to swine (Kodama et al., 1968).

From the view point of the public health, the use of live attenuated JE virus vaccine for swine might involve the risk of disseminating the virus by mosquitoes if the vaccination induced viremia in some swine due to an insufficient attenuation of the virus. Therefore, a rigid experimental confirmation of this point must precede field trial with a live vaccine even though viremia was not demonstrated with this attenuated virus among a limited number of swine previously tested.

The purpose of this study is firstly to determine the susceptibility of the

* 高橋三雄 (国立予防衛生研究所衛生昆虫部)

** 矢部貞雄・岡田寿子 (国立予防衛生研究所ウイルスリケッチァ部) 
vector mosquito to the candidate strain after passages of the virus in various animals including mosquitoes, secondly to know changes in other properties of strain after these passages, and lastly to propose a standardization of a safety test of live attenuated JE virus vaccine for amplifiers with special regard to the infectivity to vector mosquitoes.

\section{MAterials AND Methods}

Virus and virus diluent: The $\mathrm{m}$ strain of an attenuated JE virus prepared in pig kidney stable cell (PS) tube cultures (Inoue, 1964) was supplied by Dr. Y. Kanda Inoue of the Kyoto University and used in this study. The original frozendried virus had a titer of $7.8 \log \mathrm{TCD}_{50}$ per $\mathrm{ml}$ as determined in PS tube culture when the virus was resuspended in $1 \mathrm{ml}$ of distilled water. Passages of the $\mathrm{m}$ strain into suckling mouse brains were performed 12 times and coded as $\mathrm{m}$ p. SM1 to $\mathrm{m}$ p. SM12, respectively. A newborn chicken was inoculated subcutaneously with the $\mathrm{m}$ strain. The virus appearing in the chicken blood was further propagated twice in suckling mouse brains and coded as $\mathrm{m}$. Ch1SM2. Culex tritaeniorhynchus summorosus was allowed to feed on $\mathrm{m}$. SM2 virus with a membrane feeding technique, and infected mosquitoes were bred for 20 days at $28 \mathrm{C}$. The mosquitoes were then ground in a mortar and the virus was propagated once in suckling mouse brains to prepare m p. SM2CT1SM1 virus. Similar procedures were adopted for $\mathrm{m}$ p. SM6 and $\mathrm{m}$ p. SM12 viruses to obtain $\mathrm{m}$ p. SM6CT1SM1 and $\mathrm{m}$ p. SM12CT1SM1 viruses.

Mukai strain, from which the attenuated $m$ strain was derived, was also supplied by Dr. Inoue and used at the 9th suckling mouse brain passage level. JaGAr \#01 strain p. SM9 was also used as a representative epidemic strains.

Phosphate buffered saline containing 2 to $10 \%$ calf serum (CSS) was used as a virus diluent and as a diluent for mosquito suspensions.

Mosquitoes: A laboratory colony of Culex tritaeniorhynchus summorosus which has been maintained in our laboratory was used throughout the study. A modified membrane feeding technique was employed to infect mosquitoes with virus as described below, except in mosquito infection with viremic chickens. Three volumes of fresh heparinized rabbit blood were mixed with 1 volume of virus suspension and distributed into small glass tubes. Nylon gauze was chosen as the membrane instead of animal skin and fixed onto tops of glass tubes with rubber bands. Tubes were then warmed up to $37 \mathrm{C}$ and invertedly put onto tops of mosquito cages. Mosquitoes were allowed to feed on the virus-blood mixture for 15 minutes through the mesh of cages and nylon membranes.

For feeding of mosquitoes from chickens, infected chickens were fastened onto wooden plates with plasters and shaved. These chickens were inserted in mosquito cages and mosquitoes were allowed to feed on the chickens for 30 minutes.

Mosquitoes fed blood by these methods were bred for 10 days at $28 \mathrm{C}$ with a $2.5 \%$ sugar water and tested for virus. In fluorescent antibody experiments, mosquitoes were bred for $20-21$ days at $28 \mathrm{C}$ and used.

Detection of mosquito infection was usually made by intracerebral (IC) inoculation of a mosquito suspension into suckling mice, unless otherwise described. 
One $\mathrm{ml}$ of CSS for individual mosquito and $2 \mathrm{ml}$ of CSS for a pool of 10 or more mosquitoes were chosen as the amount of diluent to prepare the mosquito suspensions.

Chickens: One-day-old white Leghorn chickens were used in this study, but exact ages differed slightly among experiments. Chickens were supplied as eggs or at the newborn age from the Kobuchizawa Farm of the Nippon Institute for Biological Sciences, in which the flocks have been specially colonized to be prevented from the natural infection. Each chicken usually received $0.1 \mathrm{ml}$ of a virus suspension subcutaneously in the case of inoculation. For the titration of viremia, blood was withdrawn from the heart, just after the mosquito feeding, with a heparinized syringe and the plasma was titrated for virus using mice.

Mice: Three to 4-day-old suckling mice of dd, gpc and RFVL strains were used as hosts for virus titration, detection of mosquito infection and preparation of viruses. Each animal received $0.02 \mathrm{ml}$ of the suspension intracerebrally.

Young adult mice of dd strain, weighing $13-15 \mathrm{~g}$, were used for test of the intracerebral and intraperitoneal virulence of various viruses. Each adult mouse received $0.03 \mathrm{ml}$ of virus intracerebrally or $0.2 \mathrm{ml}$ intraperitoneally.

Other techniques: The hemagglutination test was performed as described by Okuno et al. (1965). Primary hamster kidney (HK) cell cultures were prepared in tubes as stated by Diercks and Hammon (1958). Fluorescent antibody technique was applied to mosquito salivary glands with a labeled antiserum supplied by Dr. Y. Aoyama of the Tokyo University, but the detail of the technique will appear in a future publication. Calculation of virus titer was made by the method of Reed and Muench (1938).

\section{RESULTS}

\section{Infectivity of the Attenuated $m$ Strain to the Mosquito, Culex tritaeniorhynchus summorosus}

In this experiment, various concentrations of the $\mathrm{m}$ strain of $\mathrm{JE}$ virus were directly mixed with rabbit blood, and the mixtures were given to mosquitoes by the membrane feeding technique to determine the susceptibility of the mosquito to the virus. Since the amount of blood meal for individual mosquitoes was estimated to be $2 \mathrm{mg}$, the virus amount ingested by a mosquito was calculated from the virus dilution used and the mixing ratio of blood and virus $(3: 1)$, and expressed as $\log \mathrm{TCD}_{50}$ per $0.002 \mathrm{ml}$ as determined in PS tube culture. Detection of mosquito infection was made by three methods; intracerebral inoculation into suckling mice, inoculation into primary hamster kidney culture tubes and the fluorescent antibody staining of mosquito salivary glands. Mosquitoes were not pooled but tested individually for virus by either of these three methods. As summarized in Table 1, the virus was not demonstrated from mosquitoes fed on 4 concentrations of the virus $\left(3.9,3.5,2.5\right.$ and $\left.1.5 \log \mathrm{TCD}_{50}\right)$.

\section{Viremia of the $m$ Strain in Newborn Chickens Resulting in Infection of Mosquitoes}

As Kodama et al. (1968) reported, colostrum-deprived pigs did not produce viremia after inoculation of the $\mathrm{m}$ strain. Therefore, newborn chickens were 
Table 1. Infection of $\mathrm{m}$ strain to the mosquito, Culex tritaeniorhynchus summorosus tested by a membrane feeding technique

\begin{tabular}{ccccc}
$\begin{array}{c}\text { Virus titer } \\
\text { ingested by single } \\
\text { mosquito* }\end{array}$ & \multicolumn{2}{c}{ Detection of mosquito infection by methods } & Total \\
\cline { 2 - 4 } & $\begin{array}{c}\text { Immunofluorescence } \\
\text { in salivary glands }\end{array}$ & $\begin{array}{c}\text { Suckling mice } \\
\text { intracerebral }\end{array}$ & $\begin{array}{c}\text { Primary HK } \\
\text { tube culture }\end{array}$ & \\
\hline 3.9 & $0 / 6^{* *}$ & $0 / 27$ & $0 / 18$ & $0 / 51$ \\
3.5 & $0 / 30$ & $0 / 30$ & $\mathrm{NT}^{* * *}$ & $0 / 60$ \\
2.5 & $0 / 30$ & $0 / 33$ & $\mathrm{NT}$ & $0 / 63$ \\
1.5 & $0 / 7$ & $0 / 3$ & $\mathrm{NT}$ & $0 / 10$ \\
\hline
\end{tabular}

* Log $\mathrm{TCD}_{50} / 0.002 \mathrm{ml}$ as determined by PS tube culture.

** No. mosquitoes infected/no. mosquitoes tested.

*** Not tested.

selected as a more susceptible host to determine the infectivity to C. $t$. summorosus of the virus in blood. In this series of experiments, virus titer was expressed as the positive logarhism of suckling mouse (SM) ICLD $D_{50}$, and the results are listed in Table 2.

In Experiment I, 15 chickens were inoculated with $5.9 \log \mathrm{LD}_{50}$ of the virus and virus content in plasma of 3 chickens were titrated after every $24 \mathrm{hr}$ for 5 days. Chickens were shown to produce viremia almost throughout the period, although viremia was always low in titer.

In Experiment II, 10 chickens were inoculated with $4.5 \log \mathrm{LD}_{50}$ of the virus. Virus in blood was not titrated in this experiment but its presence was determined by the mortality of suckling mice after inoculation of undiluted chicken plasma. Viremia was demonstrated from almost all chickens for 4 days after the virus inoculation, but mosquitoes fed on these chickens unexceptionally failed to show the virus infection.

In Experiment III, 9 chickens were inoculated with $5.6 \log \mathrm{LD}_{50}$ of the virus immediately after the hatching while still wet and feeble. In this case, chickens produced higher titers of viremia from 1 to 3 days after the inoculation although the endpoints of titration were missed in some chickens. Most of the mosquitoes fed on chickens in this experiment were also negative for virus infection in spite of the large number of individuals tested, but one pool containing 20 mosquitoes fed on Chicken D ( 2 days after the inoculation) had a low titer of virus after a 10-day breeding. The presence of one virus-positive pool may suggest the risk of mosquito infection if mosquitoes ingested $10^{1.3} L_{50}$ or more virus from a viremic blood.

\section{Effect of Passages of the $m$ Strain on the Infectivity to the Mosquito}

The chief object of the experiments recorded in this paragraph was to determine whether this strain of $\mathrm{JE}$ virus could regain the infectivity to mosquitoes after multiplication in mosquito tissues. Passages of the $\mathrm{m}$ strain were made in suckling mouse brains, chickens and mosquitoes, as described in Materials and Methods. Chickens were inoculated with these viruses, and mosquitoes were 
Table 2. Chicken viremia with $\mathrm{m}$ strain and mosquito inection from viremic chickens

Experiment I (Inoculum dose $=10^{5.9}$ )

\begin{tabular}{cccccc}
\hline Days after inoculation & 1 & 2 & 3 & 4 & 5 \\
\hline Virus titer of & 0.4 & trace & $<0.0$ & none & none \\
chicken blood & 0.5 & trace & 0.6 & trace & 0.5 \\
$($ Log SMICLD & 1.0 & 0.9 & 1.5 & 0.0 & $\geq 1.9$ \\
\hline
\end{tabular}

Experiment II (Inoculum dose $=10^{4.5}$ )

\begin{tabular}{cccc}
\hline $\begin{array}{c}\text { Days after } \\
\text { inoculation }\end{array}$ & Chicken No. & Chicken viremia & Mosquito infection \\
\hline \multirow{2}{*}{1} & $\mathrm{~A}$ & $+(3 / 8)^{*}$ & $0 / 20^{* *}$ \\
2 & $\mathrm{~B}$ & $+(8 / 8)$ & $0 / 35$ \\
& $\mathrm{C}$ & $-(0 / 7)$ & $0 / 10$ \\
3 & $\mathrm{D}$ & $+(2 / 10)$ & $0 / 20$ \\
& $\mathrm{E}$ & $+(8 / 8)$ & $0 / 26$ \\
& $\mathrm{~F}$ & $+(7 / 7)$ & $0 / 21$ \\
& $\mathrm{G}$ & $+(4 / 10)$ & $0 / 39$ \\
& $\mathrm{H}$ & $-(0 / 9)$ & $0 / 67$ \\
& $\mathrm{I}$ & $-(0 / 7)$ & $0 / 57$ \\
& $\mathrm{~J}$ & $-(0 / 10)$ & $0 / 49$ \\
\hline
\end{tabular}

Experiment III (Inoculum dose $=10^{5.6}$ )

\begin{tabular}{ccccc}
\hline $\begin{array}{c}\text { Days after } \\
\text { inoculation }\end{array}$ & Chicken No. & $\left.\begin{array}{c}\text { Viremia titer } \\
\text { (Log SMICLD }\end{array}\right)$ & $\begin{array}{c}\text { No. of } \\
\text { Mosquitoes }\end{array}$ & $\begin{array}{c}\text { Mosquito } \\
\text { infection }\end{array}$ \\
\hline \multirow{2}{*}{1} & A & 0.9 & 28 & $0 / 1^{* * *}$ \\
& B & 0.6 & 57 & $0 / 1$ \\
& C & 1.0 & 23 & $0 / 1$ \\
2 & D & $>2.3$ & 112 & $1 / 6$ \\
& E & 1.2 & 100 & $0 / 4$ \\
3 & F & 72.4 & 79 & $0 / 4$ \\
& G & 1.6 & 72 & $0 / 3$ \\
& H & $>2.5$ & 62 & $0 / 4$ \\
& I & $>2.5$ & 63 & $0 / 3$ \\
\hline
\end{tabular}

* No. of suckling mice died/no. of suckling mice inoculated.

** No. of mosquitoes infected/no. of mosquitoes tested.

*** No. of pools positive/no. of pools tested.

allowed to feed on chickens at $72 \mathrm{hr}$ after the inoculation. Virus titers of viremic blood and the infection rate of mosquitoes are arranged in Table 3 in the sequence of passage levels. The results presented in Table 3 showed that the ability of the $\mathrm{m}$ strain to cause viremia in chickens was not markedly enhanced following serial passages in various hosts, and that the infection rates of mosquitoes fed on these chickens were kept always low on the basis of the point estimate by the formula of Chiang and Reeves (1962). In fact, virus titers in chicken viremia were generally higher than described in the preceding paragraph and sometimes mosquito infection rates as low as $1 \%$ were observed. In a few cases, as observed 
Table 3. Chicken viremia with various passages of $m$ strain and mosquito infection from viremic chickens

Mukai p. SM9

\begin{tabular}{c|c|c|c|c|c}
\hline $\mathrm{A}$ & $\mathrm{B}$ & $\mathrm{C}$ & $\mathrm{D}$ & $\mathrm{E}$ & $\mathrm{F}$ \\
\hline \multirow{4}{*}{4.9} & 1 & 3.7 & 64 & $6 / 6$ & N. D. \\
& 2 & 4.3 & 57 & $6 / 6$ & N. D. \\
& 3 & 4.5 & 65 & $6 / 6$ & N. D. \\
& 4 & 4.3 & - & - & - \\
& 5 & 3.7 & - & - & - \\
\hline
\end{tabular}

m p. SM2

\begin{tabular}{|c|c|c|c|c|c|}
\hline $\mathrm{A}$ & B & $\mathrm{C}$ & $\mathrm{D}$ & $\mathrm{E}$ & $\mathrm{F}$ \\
\hline \multirow{2}{*}{5.2} & 1 & 3.7 & 57 & $1 / 6$ & 1.8 \\
\hline & 2 & 2.6 & 50 & $0 / 5$ & 0 \\
\hline \multirow{3}{*}{5.4} & 3 & 1.8 & 85 & $0 / 8$ & 0 \\
\hline & 4 & 3.1 & 160 & $3 / 8$ & 2.3 \\
\hline & 5 & 1.3 & 180 & $0 / 9$ & 0 \\
\hline \multicolumn{6}{|c|}{ m p. SM6 } \\
\hline $\mathrm{A}$ & $\mathrm{B}$ & $\mathrm{C}$ & $\mathrm{D}$ & $\mathrm{E}$ & $\mathrm{F}$ \\
\hline \multirow{5}{*}{5.0} & 1 & 2.7 & 130 & $2 / 7$ & 1.7 \\
\hline & 2 & 2.3 & 98 & $0 / 5$ & 0 \\
\hline & 3 & N. D. & 98 & $1 / 5$ & 1.1 \\
\hline & 4 & 1.9 & - & - & - \\
\hline & 5 & 2.9 & - & - & - \\
\hline \multicolumn{6}{|c|}{ m p. SM12 } \\
\hline A & $\mathrm{B}$ & $\mathrm{C}$ & $\mathrm{D}$ & $\mathrm{E}$ & $\mathrm{F}$ \\
\hline \multirow{5}{*}{5.8} & 1 & 2.0 & 166 & $0 / 8$ & 0 \\
\hline & 2 & 2.6 & 80 & $0 / 8$ & 0 \\
\hline & 3 & 3.5 & 60 & $0 / 6$ & 0 \\
\hline & 4 & 3.8 & - & - & - \\
\hline & 5 & 2.8 & - & - & - \\
\hline
\end{tabular}

m p. Chl SM2

\begin{tabular}{c|c|r|c|c|c}
\hline $\mathrm{A}$ & $\mathrm{B}$ & $\mathrm{C}$ & $\mathrm{D}$ & $\mathrm{E}$ & $\mathrm{F}$ \\
\hline \multirow{6}{*}{6.2} & 1 & 2.1 & 122 & $0 / 12$ & 0 \\
& 2 & 2.2 & 140 & $0 / 14$ & 0 \\
& 3 & $<0.7$ & 116 & $0 / 6$ & 0 \\
& 4 & 1.5 & - & - & - \\
& 5 & $<0.7$ & - & - & - \\
\hline
\end{tabular}

m p. SM2 CT1 SM1

\begin{tabular}{c|c|c|c|c|l}
\hline $\mathrm{A}$ & $\mathrm{B}$ & $\mathrm{C}$ & $\mathrm{D}$ & $\mathrm{E}$ & \multicolumn{1}{|c}{$\mathrm{F}$} \\
\hline \multirow{5}{*}{5.2} & 1 & 1.7 & 120 & $0 / 12$ & 0 \\
& 2 & 3.1 & 105 & $1 / 11$ & 0.9 \\
& 3 & 3.1 & 63 & $0 / 6$ & 0 \\
& 4 & 2.5 & - & - & - \\
& 5 & 2.3 & - & - & - \\
\hline
\end{tabular}

m p. SM6 CT1 SM1

\begin{tabular}{c|c|c|c|c|c}
\hline $\mathrm{A}$ & $\mathrm{B}$ & $\mathrm{C}$ & \multicolumn{1}{c|}{$\mathrm{D}$} & \multicolumn{1}{c}{$\mathrm{E}$} & \multicolumn{1}{c}{$\mathrm{F}$} \\
\hline \multirow{5}{*}{5.8} & 1 & $<0.7$ & 240 & $0 / 12$ & 0 \\
& 2 & 3.5 & 179 & $6 / 9$ & 5.3 \\
& 3 & 2.3 & 245 & $2 / 12$ & 0.9 \\
& 4 & 2.1 & - & - & - \\
& 5 & 3.7 & - & - & - \\
\hline
\end{tabular}

m p. SM12 CT1 SM1

\begin{tabular}{c|c|c|r|l|l}
\hline $\mathrm{A}$ & $\mathrm{B}$ & $\mathrm{C}$ & $\mathrm{D}$ & $\mathrm{E}$ & $\mathrm{F}$ \\
\hline & 1 & 2.4 & 72 & $1 / 7$ & 1.5 \\
& 2 & 2.5 & 110 & $0 / 11$ & 0 \\
6.2 & 3 & 1.7 & 90 & $0 / 9$ & 0 \\
& 4 & 2.4 & - & - & - \\
& 5 & 2.1 & - & - & - \\
\hline
\end{tabular}

Column A: Virus amount in the inoculum to chickens as determined by $\log$ SMICLD $_{50}$ per $0.02 \mathrm{ml}$.

B: Chicken No.

$\mathrm{C}$ : Virus titer in viremic blood of chickens as determined by $\log$ SMICLD 50 per $0.02 \mathrm{ml}$.

D: No. of mosquitoes fed on chicken.

E: No. pools positive/no. pools tested.

$\mathrm{F}$ : Point estimate of mosquito infection rate $(\%)$. 
in Chicken $\# 4$ infected with $\mathrm{m}$ p. SM2 and Chicken $\# 2$ with $\mathrm{m}$ p. SM6CT1SM1, infection rates of mosquitoes attained to 2 to $5 \%$ when the virus titers of viremic blood exceeded $10^{3.0} \mathrm{LD}_{50}$ per $0.02 \mathrm{ml}$.

On the contrary, virus titer of viremic blood of chickens inoculated with the parent Mukai strain were prominently higher than those with the $m$ strain derivatives and the infection rates of mosquitoes fed on the former chickens were unexceptionally too high to be determined.

In summarizing the above facts, the infectivity of the $\mathrm{m}$ strain to the mosquito C. $t$. summorosus, was quite poor with this virus of whatever passage history. This poor infectivity seemed to be stable even after passage in the mosquito itself or repeated propagations in suckling mouse brains. Since the parent Mukai strain had a high infectivity to the mosquito, the low infectivity of the m strain to the mosquito may have resulted from the attenuation course.

\section{Changes of the $m$ Strain in the Intraperitoneal Virulence for Young Adult Mice Caused by Passages}

As Inoue (1964) already reported, the intracerebral virulence of the $m$ strain markedly reversed after its multiplication in suckling mouse brains. Experiments were therefore performed to determine the changes of the $m$ strain in the intraperitoneal virulence for $13-15 \mathrm{~g}$ adult mice after various passage histories described above. As representative wild type strains, the Mukai and JaGAr $\# 01$ strains were used and compared with the $\mathrm{m}$ strain and its derivatives. Each virus was decimally diluted and 5 adult mice were inoculated intraperitoneally with each dilution. The virulence was expressed as the number of deaths in each dilution during a 3-week observation (Fig. 1). Intracerebral titrations were made using adult mice and shown in the figure.

The intraperitoneal virulence of the $m$ strain slightly increased following the passages but still differed from the wild type strains, Mukai and JaGAr $\# 01$. There was again no tendency of reversion of virulence through the passages of the viruses in mosquitoes. Intracerebral titers of the $\mathrm{m}$ strain derivatives in mice were rapidly raised up to the level of the wild type strains following advanced passage levels.

\section{Effect of Passages of the $m$ Strain on the Patterns of Hemagglutination}

As one of the stable markers to differentiate epidemic strains from laboratory fixed strains of JE virus, the difference in the optimum $\mathrm{pH}$ in hemagglutination was studied by Okuno et al. (1965). The pattern of hemagglutination of the $\mathrm{m}$ strain has not been known as yet. The purpose of the experiment shown in this paragraph was to know the character of hemagglutination of the $\mathrm{m}$ strain and to determine the variability of the patterns caused by the virus passaged in various hosts including mosquitoes. The material was started from $\mathrm{m}$ p. SM1 virus and various passage lines were made as stated in the preceding paragraphs. Table 4 indicates the variability of the hemagglutination pattern with $\mathrm{m} \mathrm{p}$. SM1 to SM5 viruses and not with p. SM2 virus. Earliar passages of the virus showed low titers of hemagglutination accompanied by occasional slips. The highest optimum 

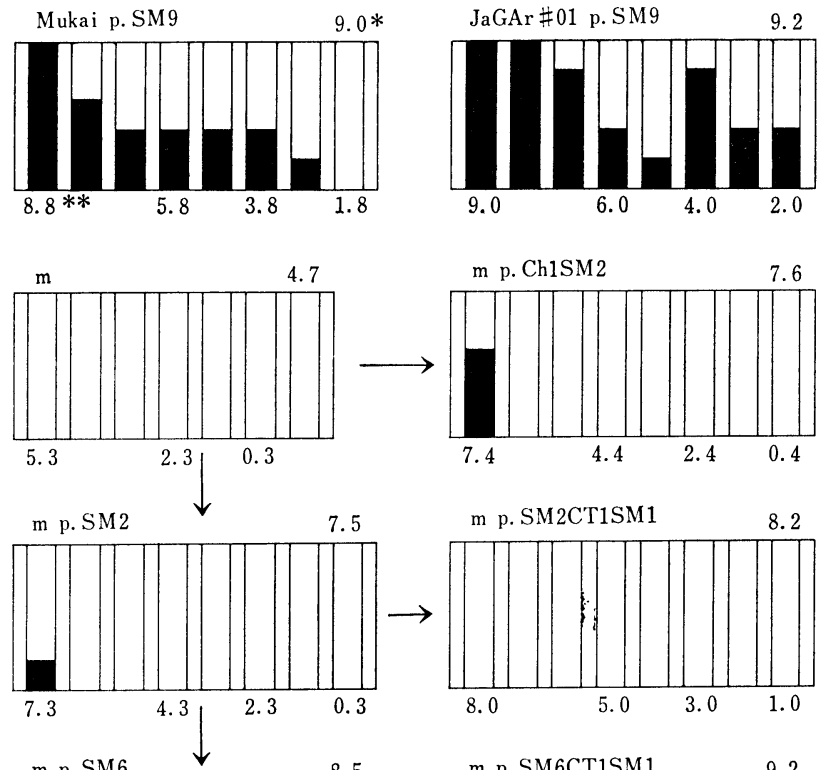

m p. SM2CT1SM1
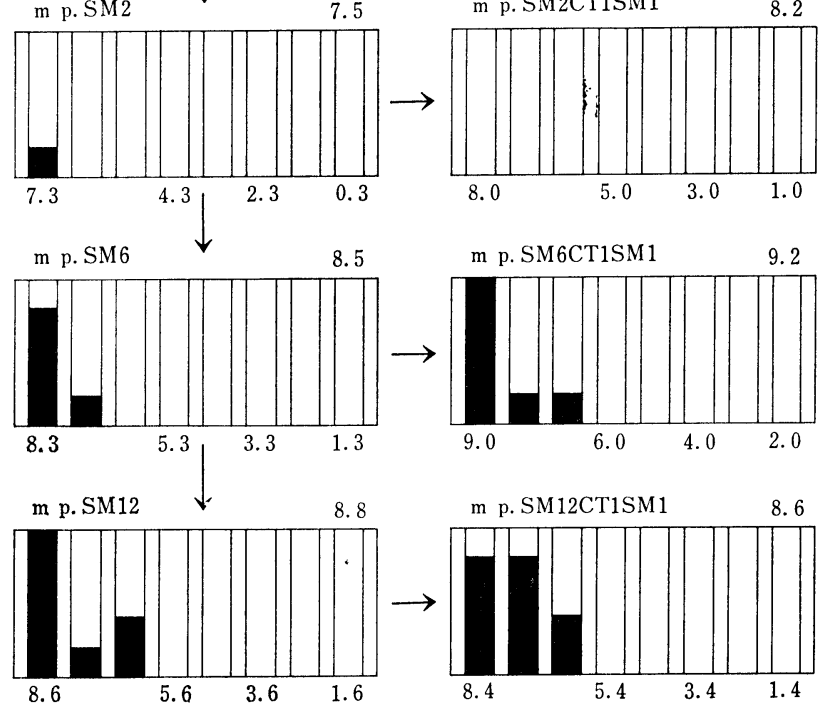

Died $\square$ Survived

* Suckling mouse brain or tissue culture fluid titer of each virus expressed in logarithm of $13-15 \mathrm{~g}$ mice $\operatorname{ICLD}_{50}$ per $0.03 \mathrm{ml}$.

** IP inoculum expressed as the titer in logarithm of $13-15 \mathrm{~g}$ mice IC lethal unit per $0.2 \mathrm{ml}$.

Fig. 1. Changes in intraperitoneal virulence of JaGAr\#01, Mukai and various passages of the attenuated $\mathrm{m}$ strain for $13-15 \mathrm{~g}$ mice.

$\mathrm{pH}$ in the case of these viruses was invariably 6.4 as has been the case of Nakayama-NIH strain. Further passages of the virus in various hosts did not greatly modify the optimum $\mathrm{pH}$, which shifted to 6.2 in some cases (Table 5). The highest optimum $\mathrm{pH}$ of the Mukai strain was 6.6 like those of fresh isolates of $\mathrm{JE}$ virus (Table 5). The stability in the hemagglutination pattern of the $\mathrm{m}$ strain through passages was also observed in this experiment. 
Table 4. Transition of hemagglutination pattern of the attenuated $\mathrm{m}$ strain following mouse passages

\begin{tabular}{|c|c|c|c|c|c|c|c|c|c|c|c|}
\hline & $\mathrm{pH}$ & $100^{*}$ & & & 800 & & & & 2,800 & & \\
\hline & 6.0 & + & + & + & + & 0 & 0 & 0 & 0 & 0 & 0 \\
\hline $\mathrm{m}$ & 6.2 & + & + & + & + & \pm & 0 & 0 & 0 & 0 & 0 \\
\hline p. SM1 & 6.4 & +8 & +8 & +8 & $+\mathrm{s}$ & \pm & 0 & 0 & 0 & 0 & 0 \\
\hline $1: 800$ & 6.6 & +8 & +8 & +8 & \pm & 0 & 0 & 0 & 0 & 0 & 0 \\
\hline opt. $\mathrm{pH}=6.4$ & 6.8 & +8 & +8 & \pm & 0 & 0 & 0 & 0 & 0 & 0 & 0 \\
\hline & 7.0 & 0 & 0 & 0 & 0 & 0 & 0 & 0 & 0 & 0 & 0 \\
\hline & 6.0 & + & + & + & + & + & + & \pm & 0 & 0 & 0 \\
\hline $\mathrm{m}$ & 6.2 & + & + & + & + & + & + & + & $0^{*}$ & 0 & 0 \\
\hline p. SM3 & 6.4 & + & + & + & + & + & + & + & $0^{*}$ & 0 & 0 \\
\hline $1: 6,400$ & 6.6 & + & + & + & + & + & + & $(+)$ & $0^{*}$ & 0 & 0 \\
\hline opt. $\mathrm{pH}=6.4$ & 6.8 & $+\mathrm{s}$ & +8 & + & + & + & \pm & 0 & 0 & 0 & 0 \\
\hline & 7.0 & + & $0^{*}$ & 0 & 0 & 0 & 0 & 0 & 0 & 0 & 0 \\
\hline & 6.0 & + & + & + & + & $(+)$ & 0 & 0 & 0 & 0 & 0 \\
\hline $\mathrm{m}$ & 6.2 & + & + & + & + & + & $+s$ & 0 & 0 & 0 & 0 \\
\hline p. SM4 & 6.4 & + & + & + & + & + & $+\mathrm{s}$ & $0 *$ & 0 & 0 & 0 \\
\hline $1: 3,200$ & 6.6 & + & + & + & + & + & \pm & 0 & 0 & 0 & 0 \\
\hline opt. $\mathrm{pH}=6.4$ & 6.8 & + & + & + & + & $0^{*}$ & 0 & 0 & 0 & 0 & 0 \\
\hline & 7.0 & $(+)$ & \pm & 0 & 0 & 0 & 0 & 0 & 0 & 0 & 0 \\
\hline & 6.0 & + & + & + & + & + & $(+)$ & 0 & 0 & 0 & 0 \\
\hline $\mathrm{m}$ & 6.2 & + & + & + & + & + & + & + & 0 & 0 & 0 \\
\hline p. SM5 & 6.4 & + & + & + & + & + & + & + & $(+)$ & 0 & 0 \\
\hline $1: 12,800$ & 6.6 & + & + & + & + & + & + & $(+)$ & 0 & 0 & 0 \\
\hline opt. $\mathrm{pH}=6.4$ & 6.8 & + & + & + & + & $(t)$ & \pm & $0^{*}$ & 0 & 0 & 0 \\
\hline & 7.0 & + & $(t)$ & \pm & 0 & 0 & 0 & 0 & 0 & 0 & 0 \\
\hline
\end{tabular}

+ Positive agglutination

(+) Partial agglutination

$0 *$ Almost negative

* Antigen dilution (1: ). +s Agglutination with slip \pm Trace agglutination

0 Negative 
Table 5. Variability of hemagglutination patterns in Mukai strain and that of the attenuated $\mathrm{m}$ strain at various passage levels

\begin{tabular}{|c|c|c|c|c|c|c|c|c|}
\hline & $\mathrm{pH}$ & $1,000^{*}$ & & & 6,0 & & & \\
\hline & 0.0 & ++ & + & \pm & 0 & 0 & 0 & 0 \\
\hline Mukai & 6.2 & ++ & + & + & + & 0 & 0 & 0 \\
\hline SM9 & 6.4 & ++ & + & + & + & $0 *$ & 0 & 0 \\
\hline $1: 16,000$ & 6.6 & ++ & + & + & + & 0 * & 0 & 0 \\
\hline opt. $\mathrm{pH}=6.6$ & 6.8 & $+\quad+$ & + & $(+)$ & 0 & 0 & 0 & 0 \\
\hline & 7.0 & $+(t)$ & 0 & 0 & 0 & 0 & 0 & 0 \\
\hline
\end{tabular}

\begin{tabular}{|c|c|c|c|c|c|c|c|c|c|}
\hline & $\mathrm{pH}$ & 1,00 & & & &, & & & \\
\hline & 6.0 & + & + & $(+)$ & () & 0 & ( & & \\
\hline $\mathrm{m}$ & 6.2 & $t$ & + & + & +1 & 0 & ( & 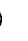 & 0 \\
\hline Ch1 SM2 & 6.4 & + & + & + & + & 0 & & ) & 0 \\
\hline $1: 8,000$ & 6.6 & + & + & + & $(+)$ & 0 & & ) & 0 \\
\hline opt. $\mathrm{pH}=6.4$ & 6.8 & $(+)$ & 0 & 0 & 0 & 0 & & 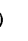 & 0 \\
\hline & 7.0 & 0 & 0 & 0 & 0 & 0 & & ). & 0 \\
\hline
\end{tabular}

\begin{tabular}{|c|c|c|c|c|c|c|c|c|}
\hline & 6.0 & + & $+(t)$ & 0 & 0 & 0 & 0 & 0 \\
\hline $\mathrm{m}$ & 6.2 & & ++ & + & 0 & 0 & 0 & 0 \\
\hline $\mathrm{SM} 2$ & 6.4 & + & ++ & $(t)$ & 0 & 0 & 0 & 0 \\
\hline $1: 8,000$ & 6.6 & & ++ & $0^{*}$ & 0 & 0 & 0 & 0 \\
\hline opt. $\mathrm{pH}=6.2$ & 6.8 & $0 *$ & $\begin{array}{ll}0 & 0\end{array}$ & 0 & 0 & 0 & 0 & 0 \\
\hline & 7.0 & 0 & $\begin{array}{ll}0 & 0\end{array}$ & 0 & 0 & 0 & 0 & 0 \\
\hline & & & $\downarrow$ & & & & & \\
\hline & 6.0 & + & $+\quad+$ & & $0 *$ & 0 & 0 & 0 \\
\hline $\mathrm{m}$ & 6.2 & + & $+\quad+$ & + & + & \pm & 0 & () \\
\hline SM7 & 6.4 & + & ++ & + & $(+)$ & \pm & 0 & 0 \\
\hline $1: 16,000$ & 6.6 & + & $+\quad+$ & $(+)$ & $0 *$ & 0 & () & ) \\
\hline opt. $\mathrm{pH}=6.2$ & 6.8 & 0 & $0 \quad 0$ & 0 & 0 & o & () & 0 \\
\hline & 7.0 & 0 & $0 \quad 0$ & 0 & 0 & 0 & 0 & 0 \\
\hline & & & $\downarrow$ & & & & & \\
\hline & 6.0 & + & ++ & $(+)$ & 0 & 0 & 0 & 0 \\
\hline $\mathrm{m}$ & 6.2 & + & $+\quad+$ & + & $(+)$ & 0 & 0 & 0 \\
\hline SM12 & 6.4 & + & ++ & $(+)$ & 0 & 0 & 0 & 0 \\
\hline $1: 16,000$ & 6.6 & + & $+\quad+$ & $0^{*}$ & 0 & 0 & 0 & 0 \\
\hline opt. $\mathrm{pH}=6.2$ & 6.8 & 0 & $0 \quad 0$ & 0 & 0 & 0 & 0 & 0 \\
\hline & 7.0 & 0 & $\begin{array}{ll}0 & 0\end{array}$ & 0 & 0 & 0 & 0 & 0 \\
\hline
\end{tabular}

\begin{tabular}{|c|c|c|c|c|c|c|c|c|c|}
\hline & 6.0 & + & + & $(t)$ & 0 & 0 & 0 & 0 & 0 \\
\hline $\mathrm{m}$ & 6.2 & + & + & & t. & \pm & 0 & 0 & 0 \\
\hline$\rightarrow \underset{\text { SM1 }}{\mathrm{SM} 2 \mathrm{CT} 1}$ & 6.4 & + & + & & + & \pm & 0 & 0 & () \\
\hline $1: 8,000$ & 6.6 & + & + & + & \pm & 0 & 0 & 0 & 0 \\
\hline \multirow[t]{2}{*}{ opt. $\mathrm{pH}=6.4$} & 6.8 & 0 & 0 & 0 & 0 & 0 & 0 & 0 & 0 \\
\hline & 7.0 & 0 & 0 & 0 & 0 & 0 & 0 & 0 & 0 \\
\hline
\end{tabular}

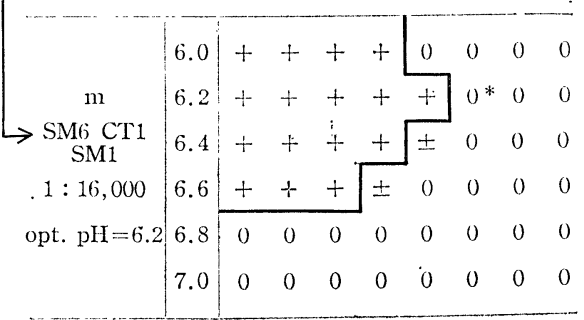

+ Positive agglutination

\pm Trace agglutination

(+) Partial agglutination

* Antigen dilution (1: ).

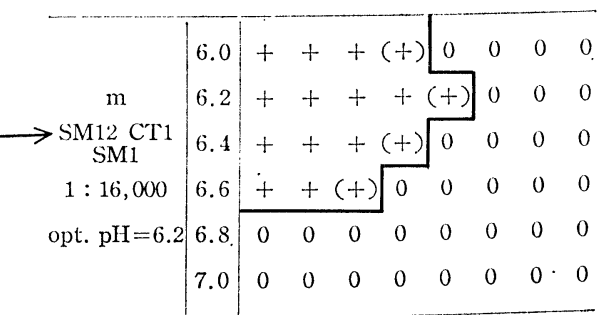

\section{Discussion}

Studies similar to our experiments presented herein were reported by Whitman (1939) on 17D yellow fever virus, by Mussgay and Suarez (1962) on attenuated VEE6316 Venezuelan equine encephalitis virus and by Hardy (1966) on Clone 15 western equine encephalitis virus. These authors stated that the attenuated 
arboviruses did not alter the pathogenecities after multiplication in mosquitoes. However, these viruses were more or less infective to vector mosquitoes, and the change of infectivity for mosquitoes were not remarkable during the course of attenuation. In a study on an attenuated strain of JE virus, Rohitayodhin and Hammon (1962) found a loss of infectivity for the mosquito, Culex tritaeniorhynchus, when the virus was tested as a mixture with rabbit blood.

Our experiments showed that the attenuated $\mathrm{m}$ strain of $\mathrm{JE}$ virus had a remarkable inability to infect the vector mosquito even after passages in various hosts. Virus transmissibilities of the mosquitoes infected with the $\mathrm{m}$ strain were not tested in our study for reason of the steady low infection rate of mosquitoes. Intracerebral virulence of the viruses in mice was easily elevated through the passages, but the neurovirulence of these viruses was not parallel to their infectivity to mosquitoes.

Other properties of the $\mathrm{m}$ strain, as far as the intraperitoneal (IP) virulence for adult mice and the optimum $\mathrm{pH}$ of hemagglutination are concerned, were not essentially modified through the passages in hosts. Oya et al. (1963) classified strains of JE virus into 2 groups, lethal type and non-infective type. The former type was differentiated from the latter by the lethality to adult mice inoculated IP with less than $10^{7.0}$ baby mice lethal units (BLU) of the virus. The latter type of JE virus strains were neither lethal nor infective to adult mice with IP inoculation of this or a lower titer. Although the infectivity of the $\mathrm{m}$ strain for adult mice were not tested in our study, the virus was proved to be non-lethal to the host. The lethality of the derivatives of the $\mathrm{m}$ strain was gradually altered with the increase of passage levels, and stood halfway of the above 2 types at higher passage levels, but it was never reversed to such a lethal type as the parent Mukai or JaGAr \#01 strain. The result of hemagglutination tests also indicated a clear difference between the attenuated and fresh epidemic strains. The optimum $\mathrm{pH}$ of the $\mathrm{m}$ strain derivatives were always 6.4 or lower, while it was 6.6 or higher in the fresh JE virus isolates (Okuno et al., 1965). These properties, especially the optimum $\mathrm{pH}$ in hemagglutination, could be handy markers of this attenuated strain to differentiate it from epidemic strains of JE virus.

The newborn chicken, which has been known as a very susceptible host of arboviruses, was proved also in our study, to be an excellent experimental animal to analyze virus-vector relationships.

Several candidate strains of live attenuated JE vaccine to immunize amplifiers will appear in programs of the eradication of JE virus. Considering generally, the higher inability to infect vectors the virus gains without loss of immunogenecity, the more proper it may be for use as vaccine. Maintainance of a high grade of infectivity to vectors of the virus may not be adequate if the virus transmitted by vectors did not reverse the virulence in experimental steps. From this point of view, the strain used in this study might be judged to be a hopeful candidate for the purpose.

\section{REFERENCES}

Chiang, C. L. AND ReEves, W. C. (1962): Statistical estimation of virus infection rates in mosquito vector populations. Am. J. Hyg., 75, 377-391. 
Diercks, F. H. AND HAMmon, W. MCD. (1958): Hamster kidney cell tissue cultures for propagation of Japanese B encephalitis virus. Proc. Soc. Expt1. Biol. Med., 97, 627-632.

HARDY, J. L. (1966): Culex tarsalis Coquillett as a vector of an attenuated strain of western equine encephalomyelitis virus. Proc. Soc. Expt1. Biol. Med., 121, 402-405.

INOUE, Y. KANDA (1964): An attenuated mutant of Japanese encephalitis virus. Bulletin WHO, 3O, 181-185.

KodAma, K., SASAKI, N. AND InOUE, Y. KANDA (1968): Studies of live attenuated Japanese encephalitis vaccine in swine. J. Immunol., 10O, 194-200.

Konno, J., Endo, K., Agatsuma, H. And Ishida, N. (1966): Cyclic outbreaks of Japanese encephalitis among pigs and humans. Am. J. Epidemiol., 84, 292-300.

Mussgay, M. AND SuAREz, O. (1962): Studies with a pathogenic and an attenuated strain of Venezuelan equine encephalitis virus and Aedes aegypti (L.) mosquitoes. Arch. f. Ges. Virusfor., 12, 387-392.

OKuno, T., Suzuki, M., Kondo, A. AND Ito, T. (1965): Variability of strains of Japanese encephalitis virus in regard to the pH-dependency in hemagglutination. Japan. J. Med. Sci. Biol., 18, 227-238.

Oya, A., SAKumoto, H. AND KobayAshi, M. (1963): Variation of virulence of Japanese B encephalitis virus to adult mice. In the "Symposium on the variation of Japanese B encephalitis virus"'. Japan. J. Med. Sci. Biol., 16, 50-52.

OYA, A. (1967): The role of mammals as primary and supplementary hosts. In the "Symposium on arbovirus diseases, animal vectors and reservoirs". Japan. J. Med. Sci. Biol., 20, 26-30.

ReEd, L. J. And Muench, H. (1938): A simple method of estimating fifty percent endpoints. Am. J. Hyg., 27, 493-497.

Rohitayodhin, S. AND HAmmon, W. McD. (1962): Studies on Japanese B encephalitis virus vaccines from tissue culture. II. Development of an attenuated strain of virus. J. Immunol., 89, 589-597.

Scherer, W. F., Moyer, J. T., Izumi, T., Gresser, I. And McCown, J. (1959): Ecologic studies of Japanese encephalitis virus in Japan. VI. Swine infection. Am. J. Trop. Med. Hyg., 8, 698-706.

Whitman, L. (1939): Failure of Aëdes aegypti to transmit yellow fever cultured virus (17D). Am. J. Trop. Med., 19, 19-26. 